\title{
Effect of cashew nut shell liquid at varying inclusion levels on rumen fermentation and methane production in vitro
}

\author{
Adeola Patience Adetunji (D) . Ronke Yemisi Aderinboye (iD. Kafayat Omowunmi Adebayo (iD. \\ Victoria Olubunmi Ojo (D. Peter Ayodeji Idowu ID. Bohani Mtileni iD
}

\section{AP Adetunji - RY Aderinboye - KO Adebayo}

Department of Animal Nutrition, College of Animal Science and Livestock Production, University of Agriculture Abeokuta, Nigeria.

\section{VO Ojo}

Department of Pasture and Range Management, College of Animal Science and Livestock Production, University of Agriculture Abeokuta, Nigeria.
PA Idowu (Corresponding author) - B Mtileni

Department of Animal Sciences, Tshwane University of Technology, Private Bag X680, Pretoria 0001, South Africa.

email: ayodejiidowuolu@gmail.com

Received: March 28, 2019 • Accepted: May 13, 2019 • Published Online: November 22, 2019

\begin{abstract}
Essential oils are possible natural antibiotic alternatives for manipulating ruminal fermentation in order to improve the utilization of nutrient in ruminants. This study evaluated the effect of cashew nut shell liquid (CNSL) at varying inclusion levels on in vitro gas production, nutrient degradation, and post-incubation parameters. Experimental diets consisted of Panicum maximum (Ntchisi) grass as basal diet and supplemental pellets treated with 0, 5, 10 and 15 $\mathrm{ml} / \mathrm{kg}$ of cashew nut shell liquid. Proximate composition of experimental diets was analysed. In vitro experiment was carried out on experimental diets (P. maximum and concentrate pellets at ratio 70:30) for 24 hours using goat rumen liquor as inoculum. Results showed that CNSL inclusion had a significant effect $(P<0.05)$ on the ether extract and metabolizable energy of experimental pellets. Dietary treatment with $15 \mathrm{ml} / \mathrm{kg}$ of CNSL had the lowest $(P<0.05)$ in vitro gas production. Inclusion of CNSL significantly inhibited methane production at $5 \mathrm{ml} / \mathrm{kg}(18 \%), 10 \mathrm{ml} / \mathrm{kg}$ (34\%) and $15 \mathrm{ml} / \mathrm{kg}(57 \%)$ CNSL inclusion levels $(P<0.05)$. Ammonia-N and TVFA decreased significantly with CNSL inclusion. Significant reduction $(P<0.05)$ in short-chain fatty acid, metabolizable energy, and organic matter degradability were recorded with increasing CNSL inclusion levels.
\end{abstract}

Keywords: dietary, eco-friendly feed additive, essential oils, methane inhibition, ruminants

\section{Introduction}

Fermentation of feed in the rumen often results to substantial nutritional loss in form of methane and ammonia. The reduction in nutritional component consequently results to wasteful utilization of feed nutrients by animals and can also lead to increased feed costs (Holmes et al 2006; Gebrehiwot 2014). Improving nutritional utilization through the inhibition of methane could result in improved nutrient utilization and on the other hand, limit environmental pollutions from enteric sources (Santra and Karim 2003).

Ruminants contribute to environmental pollution due to the production of greenhouse gases $\left(\mathrm{CO}_{2}, \mathrm{CH}_{4}\right.$ and $\left.\mathrm{N}_{2} \mathrm{O}\right)$ which is the cause for climate change. The global contribution to GHG emissions by the animal sector are $9 \%$ for cabondioxide $\left(\mathrm{CO}_{2}\right), 35-40 \%$ for methane $\left(\mathrm{CH}_{4}\right)$ and $65 \%$ for nitrous oxide $\left(\mathrm{N}_{2} \mathrm{O}\right)$ (Oonincx et al, 2010). Ammonia from manure and urine is transformed via nitrification and denitrification into $\mathrm{N}_{2} \mathrm{O}$ (Oonincx et al, 2010). Nitrous oxide $\left(\mathrm{N}_{2} \mathrm{O}\right)$ is a greenhouse gas that is capable of undergoing stratospheric reaction with atomic oxygen to form nitric oxide (NO) which in turn destroys stratospheric ozone (Wrage et al., 2001). The process of producing $\mathrm{N}_{2} \mathrm{O}$ from ammonia has also been identified to lead to soil nitrogen losses (Hong et al, 2017).

Therefore, the manipulation of rumen fermentation can be considered as a nutrient optimization process (Santra and Karim 2003) and mitigation strategy for GHG emissions. To improve efficiency of nutrient utilization in ruminants and mitigate methane production, antibiotics have been progressively embraced over the years (McDougall et al 2004; Gallardo et al 2005). However, there is rise in scientific and public concern about the use of antibiotics as feed additives in animal production. This concern is driven by the occurrence of antibiotic resistance in various human pathogenic bacteria (Manero et al 2006; Parveen et al 2006) die and increased risk of growth-promoting antibiotic residues in foods of animal products (Yang and Carlson 2004). In order to combat such 
residues, there has been a great need amid animal producers and consumers for alternative feed additives which are naturally safe in human food supply chain (Jouany and Morgavi 2007). Essential oils are possibly promising natural replacements to antibiotics and ionophores for manipulating ruminal fermentation. This is due to their capacity in modifying cell permeability in microbes and toxicity to some strains of rumen microorganism (McIntosh et al 2003; Calsamiglia et al 2007). Cashew nut shell liquid is a typical essential oil that is known for its antimicrobial activities (Kozubek et al 2001). However, limited studies have been conducted to determine the effect of dietary inclusion levels of cashew nut shell liquid in ruminant diet. This study therefore, aim at evaluating the effect of cashew nut shell liquid (CNSL) on in vitro gas production, nutrient degradation and post incubation parameters.

\section{Materials and Methods}

\section{Experimental diets and procedure}

A complete concentrate supplement was compounded (Table 1) to contain approximately $14 \%$ crude protein, which is adequate for growing goats (NRC 1981). Cashew nut shell liquid was added to the concentrate at varying levels of 0,5 , 10 , and $15 \mathrm{ml} / \mathrm{kg}$ of complete diet, which made up to four dietary treatments. The concentrate was processed into pellets using cassava flour in the composition as binder, according to the different levels of CSNL inclusion.

\section{Chemical composition}

Proximate composition of experimental diets samples was determined according to the procedure of AOAC (1990). Crude protein was obtained by total $\mathrm{N}$ determination using the micro Kjeldahl technique (nitrogen content $(\mathrm{N}) \times 6.25$ ). The fibre fractions of experimental diets and faecal samples were determined according to Van Soest et al (1991). Cellulose and hemicellulose were calculated as differences between ADF and ADL and NDF and ADF respectively.

Hemicellulose $=\mathrm{NDF}-\mathrm{ADF}$

Cellulose $=\mathrm{ADF}-\mathrm{ADL}$

Organic matter content was calculated as 100 - ash content in feed. Non-structural carbohydrate (NSC) was calculated as $(100-(\mathrm{CP}+\mathrm{EE}+\mathrm{Ash}+\mathrm{NDF})(\mathrm{AOAC}, 2000)$. Metabolizable energy content was estimated as $37 \times \%$ crude protein $+81 \times \%$ ether extract $+35.5 \times \%$ nitrogen-free extract (Pauzenga 1985).

Table 1 Gross composition of experimental concentrates diets.

\begin{tabular}{lcccc}
\hline Ingredients & \multicolumn{4}{c}{ Composition $(\mathrm{g} / \mathrm{kg})$} \\
\hline Wheat offal & 533.0 & 533.0 & 533.0 & 533.0 \\
Brewers dried & 100.0 & 100.0 & 100.0 & 100.0 \\
grain & & & 170.0 & 170.0 \\
Groundnut cake & 170.0 & 170.0 & 167.0 & 167.0 \\
Cassava flour & 167.0 & 167.0 & 20.0 & 20.0 \\
Bone meal & 20.0 & 20.0 & 10.0 & 10.0 \\
Salt & 10.0 & 10.0 & ++ & +++ \\
CSNL levels & - & + & 1000 & 1000 \\
TOTAL (kg) & 1000 & 1000 & & \\
\hline $\begin{array}{l}\text { CNSL: Cashew nut shell liquid; }-0 \% \text { inclusion level of cashew nut shell liquid; }+5 \% \text { inclusion } \\
\text { level of cashew nut shell liquid; ++ 10\% inclusion level of cashew nut shell liquid; +++ }+15 \% \\
\text { inclusion level of cashew nut shell liquid. }\end{array}$ &
\end{tabular}

\section{In vitro gas production of experimental diets}

Rumen fluid used for the incubation was collected from three West African dwarf goats prior to morning feeding using suction tube as described by Babayemi and Bamikole (2006). The goats were previously fed with $40 \%$ concentrate (40\% corn, 10\% wheat offal, 10\% palm kernel cake, $20 \%$ groundnut cake, $5 \%$ soyabean meal, $10 \%$ dried brewers grain, $1 \%$ common salt, $3.75 \%$ oyster shell and $0.25 \%$ fish meal) and 60\% Panicum maximum grass. Oven-dried and milled samples of the Panicum maximum leaves and concentrate pellet according to the different treatments was incubated at the ratio 70:30 respectively with the rumen fluid in $100 \mathrm{mls}$ calibrated transparent syringes fitted with silicon tube following the procedure of Menke and Steingass (1988). Incubation was carried out at $39^{\circ} \mathrm{C}$ in an incubator and the volume of gas produced was measured at 24 hours. The methane gas produced from each sample was determined according to the procedures of Fievez et al (2005). 
The post incubation parameters were determined by calculation as follows:

Metabolizable energy $(\mathrm{ME}, \mathrm{MJ} / \mathrm{kg} \mathrm{DM})=2.20+0.136 \mathrm{GV}+$ 0.057CP + 0.0029CF (Menke and Steingass, 1988).

Organic Matter Digestibility $(\mathrm{OMD}, \%)=14.88+0.889 \mathrm{GV}+$ $0.45 \mathrm{CP}+0.651 \mathrm{XA}$ (Menke and Steingass, 1988).
Short chain fatty acids (SCFA, $\mu \mathrm{mol} / \mathrm{g} \mathrm{DM})=0.0239 \mathrm{GV}$ 0.0601(Getachew et al. 2001)

where $\mathrm{GV}, \mathrm{CP}, \mathrm{CF}$ and $\mathrm{XA}$ are total gas volume at $24 \mathrm{~h}$, crude protein, crude fibre and ash values, respectively.

After 24 hours incubation period, the residues was decanted into pre-weighed crucibles and then oven-dried at $105^{\circ} \mathrm{C}$ for $24 \mathrm{hrs}$. The dry residue was weighed and degradability calculated using the equation below:

\section{$\operatorname{IVDMD}(\%)=\underline{\text { Initial dry matter incubated }- \text { dry matter of residues } \mathrm{x} 100}$ Initial dry matter incubated}

For determination of crude protein and organic matter degradability, samples of feed incubated and the residues was collected and analysed for crude protein (CP) and organic matter (OM) content. Crude protein degradability (CPD \%) and organic matter degradability (OMD \%) was calculated thus:

\section{$\mathrm{CPD}(\%)=\underline{\mathrm{CP} \text { content of incubated sample }-\mathrm{CP} \text { content of residues }} \times 100$ $\mathrm{CP}$ content of incubated sample \\ OMD $(\%)=\quad$ OM content of incubated sample - OM content of residues $\times 100$ OM content of incubated sample}

\section{Statistical analysis}

Data generated from in vitro study was subjected to analysis of variance (ANOVA) in a completely randomized design according to the procedure of SAS (2010). Significant means were separated using Duncan multiple range test $(P<$ $0.05)$.

\section{Results and Discussion}

Table 2 shows the proximate composition of Panicum maximum (Ntchisi) fed as basal diets to West African Dwarf (WAD) goats. The Panicum maxima (Ntchisi) used in this study contained lower proportions of dry matter and this was similar to the values reported by Asaolu et al. (2014). Similarly, Aminah and Chen (1991) reported that most of the tropical pastures have crude protein contents ranging from 7 to $12 \%$ for grasses. The proximate analysis of supplemental diet is represented in table 3 . The pelletised diets containing varying levels of CNSL fed in this study had a relatively high dry matter; this may be attributed to the dry feedstuffs used in compounding the feed and the effect of the pelleting process. Cashew nut shell liquid inclusion into pelletised diets resulted in ether extract increase and this may be due to the increase in fat content of diet as inclusion of oil increased. Metabolizable energy increased across the table indicating increase in the calorie content of supplemental pellets as CNSL increases, this agrees with the report of Geelen et al. (2001).

The effect of CNSL inclusion levels on gas production and fermentation parameters are represented in table 4. Addition of CNSL decreased gas production of supplemental diets from $5 \mathrm{ml} / \mathrm{kg}$ to $15 \mathrm{ml} / \mathrm{kg}$ inclusion levels $(P<0.05)$. The decrease in cumulative gas production recorded in this study is in line with the report of Nezhad et al (2011) who observed decrease in gas production of in vitro analysis of experimental diet treated with varying levels of spearmint essential oil. Inclusion of CNSL significantly inhibited methane production from $5 \mathrm{ml} / \mathrm{kg}(18 \%), 10 \mathrm{ml} / \mathrm{kg}(34 \%)$ and $15 \mathrm{ml} / \mathrm{kg}(57 \%)$ CNSL inclusion levels $(P<0.05)$. This shows a reduction in loss of energy via methane production in ruminants.

Table 2 Nutrient composition (\%DM) of Panicum maximum fed as basal diet.

\begin{tabular}{lcc}
\hline Parameters & Composition & SEM \\
\hline Dry matter (\% as fed) & 40.70 & 1.59 \\
Crude protein & 9.00 & 0.38 \\
Ether extract & 3.25 & 1.01 \\
Ash & 7.12 & 0.11 \\
Non fibre carbohydrate & 32.06 & 0.19 \\
Organic matter & 92.88 & 0.58 \\
Neutral Detergent Fibre & 48.56 & 2.04 \\
Acid Detergent Fibre & 30.92 & 2.32 \\
Acid Detergent Lignin & 10.05 & 0.53 \\
Hemicellulose & 17.64 & 0.52 \\
Cellulose & 20.87 & 1.85 \\
\hline
\end{tabular}

NB: Average of four replicates.

Similar results have been observed in several studies. Wang et al (2009) reported in his study that inclusion of 0.25 $\mathrm{g} /$ day of essential oil mixture from oregano plants in the diet of sheep for 15 days decreased methane production. Evans and Martin (2000) observed that thymol $\left(0.4 \mathrm{~g} \mathrm{~L}^{-1}\right)$, a main 
component of essential oils derived from Thymus and Origanum plants, was a strong inhibitor of methane in in vitro study. This reduction indicates that CNSL has the potential to manipulate ruminal fermentation process favorably and maximize nutrient utilization. This study proves that CNSL inclusion in ruminant feed will reduce the contribution of methane to the global GHG emissions, as it had been reported that enteric methane is the most significant GHG gas emitted $(50 \%$ to $60 \%$ ) in ruminant production systems (Ogino et al 2007).

Ammonia N production was decreased by CNSL with significantly lower values $(P<0.05)$ at $10 \mathrm{mls}$ CNSL inclusion level. This result is in accordance with the study of Castillejos et al (2006) which found a significant reduction in ammonia$\mathrm{N}$ concentrations of rumen cultures incubated with thymol at $500-1000 \mathrm{mg} / \mathrm{L}$. The reduction of ammonia in this study shows that the inclusion of CNSL in ruminant diet promises to make ruminant production more environmental-friendly as the nitrification and acidification of soils reduces and also the production of $\mathrm{N}_{2} \mathrm{O}$.

Total volatile fatty acid increased significantly with the inclusion of CNSL compared to $0 \mathrm{ml}$ inclusion level. However, TVFA decreased in a CNSL inclusion level-dependent manner with the least value at $15 \mathrm{mls}$ when compare to $5 \mathrm{ml} / \mathrm{kg}$ and $10 \mathrm{ml} / \mathrm{kg} \mathrm{CNSL}$ inclusion level. This result supports the study of Busquet et al (2006) who reported a decrease in VFA concentration when anise oil (ANO) was added to rumen batch cultures at $3000 \mathrm{mg} / \mathrm{L}$ but no effects on VFA concentration when ANO was added at up to $300 \mathrm{mg} / \mathrm{L}$. Higher doses of cinnamon oil and cinnamaldehyde also decreased total VFA and ammonia-N concentrations (Busquet et al 2006). This result indicates that CNSL is able to modify VFA production positively, however when added at higher doses, it may result in lower efficiency of nutrient utilization in the rumen.

Table 3 Chemical composition of supplemental diets with varying levels of cashew nut shell liquid.

\begin{tabular}{|c|c|c|c|c|c|}
\hline \multirow{2}{*}{ Parameters $(\%)$} & \multicolumn{4}{|c|}{ Supplemental pellets with varying levels of CNSL } & \multirow[t]{2}{*}{ SEM } \\
\hline & $0 \mathrm{ml}$ & $5 \mathrm{ml}$ & $10 \mathrm{ml}$ & $15 \mathrm{ml}$ & \\
\hline Dry matter & 95.80 & 96.52 & 96.70 & 96.34 & 0.40 \\
\hline Crude protein & 14.02 & 14.11 & 14.00 & 14.21 & 0.22 \\
\hline Crude fibre & 10.64 & 10.70 & 10.78 & 10.66 & 0.18 \\
\hline Ether extract & $8.38^{b}$ & $10.62^{\mathrm{a}}$ & $11.15^{\mathrm{a}}$ & $11.52^{\mathrm{a}}$ & 0.42 \\
\hline Ash & 10.70 & 10.55 & 10.60 & 10.50 & 0.15 \\
\hline Neutral detergent fibre & 47.10 & 46.88 & 46.53 & 46.40 & 0.18 \\
\hline Acid detergent fibre & 20.30 & 19.82 & 19.73 & 19.06 & 0.24 \\
\hline Acid detergent lignin & 9.10 & 9.24 & 9.13 & 9.28 & 0.15 \\
\hline Organic matter & 89.30 & 89.45 & 89.40 & 89.50 & 0.15 \\
\hline NSC & $19.80^{\mathrm{a}}$ & $17.84^{b}$ & $17.72^{b}$ & $17.36^{\mathrm{b}}$ & 0.35 \\
\hline $\mathrm{ME} \mathrm{kcal} / \mathrm{kg}$ & $3194.75^{\mathrm{b}}$ & $3296.69^{\mathrm{a}}$ & $3319.22^{\mathrm{a}}$ & $3344.30^{\mathrm{a}}$ & 19.19 \\
\hline
\end{tabular}

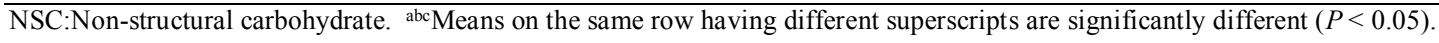

Tabel 4 Effect of various levels of CNSL inclusion on in vitro gas production (ml/g DM) and fermentation parameters.

\begin{tabular}{|c|c|c|c|c|c|}
\hline \multirow[t]{2}{*}{ Fermentation parameter } & \multicolumn{4}{|c|}{ Varying levels of CNSL } & \multirow[t]{2}{*}{ SEM } \\
\hline & $0 \mathrm{ml}$ & $5 \mathrm{mls}$ & $10 \mathrm{mls}$ & $15 \mathrm{mls}$ & \\
\hline Gas production & $54.50^{\mathrm{a}}$ & $51.50^{\mathrm{ab}}$ & $51.50^{\mathrm{ab}}$ & $47.50^{b}$ & 0.88 \\
\hline $\mathrm{CH}_{4}$ & $11.13^{\mathrm{a}}$ & $9.00^{\mathrm{ab}}$ & $7.25^{\mathrm{bc}}$ & $4.75^{\mathrm{C}}$ & 0.32 \\
\hline $\mathrm{NH}_{3}-\mathrm{N}(\mathrm{mg} / \mathrm{dL})$ & $115.67^{\mathrm{a}}$ & $103.77^{b}$ & $96.96^{\mathrm{d}}$ & $100.36^{\mathrm{C}}$ & 0.56 \\
\hline TVFA & $9.55^{\mathrm{d}}$ & $15.50^{\mathrm{a}}$ & $13.50^{\mathrm{b}}$ & $11.50^{\mathrm{C}}$ & 0.40 \\
\hline
\end{tabular}

abc Means on the same row having different superscripts are significantly different $(P<0.05)$.

$0 \mathrm{ml}$ - control diets, $5 \mathrm{ml}$ - contains $5 \mathrm{ml}$ of CNSL $/ \mathrm{kg}$ DM pelletised diet, $10 \mathrm{ml}$ - contains $10 \mathrm{ml}$ of CNSL/ $\mathrm{kg}$ DM pelletised diet, $15 \mathrm{ml}-$ contains $15 \mathrm{ml}$ of $\mathrm{CNSL} / \mathrm{kg}$ DM pelletised diet 
In the present study, short chain fatty acids recorded the lowest value when CNSL was included at $15 \mathrm{ml} / \mathrm{kg}$ in experimental diet. This agrees with the studies of Shinkai et al (2012), that feeding CNSL caused a decrease in acetate, methane emission and total short-chain fatty acid levels. In vitro dry matter degradability, crude protein degradability and organic matter degradability were affected significantly $(P<$
$0.05)$ by CNSL inclusion. The decrease observed in this study is in line with the study of Sirohi et al (2012). Sirohi et al (2012) reported that the dry matter degradability of high fibre diet incubated with garlic oil decreased by $25.92 \%$. The authors also reported that Eucalyptus oil decreased in vitro dry matter degradability by $27.13 \%$ and $23.28 \%$ in the medium fibre diet and low fibre diet respectively.

Table 5 Effect of varying levels of CNSL inclusion on in vitro post incubation parameter and nutrient degradability.

\begin{tabular}{|c|c|c|c|c|c|}
\hline \multirow[t]{2}{*}{ Post incubation parameters } & \multicolumn{4}{|c|}{ Varying levels of CNSL } & \multirow[t]{2}{*}{ SEM } \\
\hline & $0 \mathrm{ml}$ & $5 \mathrm{ml}$ & $10 \mathrm{ml}$ & $15 \mathrm{ml}$ & \\
\hline $\mathrm{SCFA}(\mu \mathrm{mol} / \mathrm{g})$ & $0.61^{\mathrm{a}}$ & $0.50^{\mathrm{b}}$ & $0.49^{\mathrm{b}}$ & $0.43^{\mathrm{b}}$ & 0.01 \\
\hline $\operatorname{ME}(\mathrm{MJ} / \mathrm{kg})$ & $6.66^{\mathrm{a}}$ & $6.00^{\mathrm{b}}$ & $5.93^{\mathrm{b}}$ & $5.53^{\mathrm{c}}$ & 0.09 \\
\hline Organic Matter digestibility (\%) & $45.49^{\mathrm{a}}$ & $41.10^{\mathrm{b}}$ & $40.54^{b}$ & $37.92^{\mathrm{c}}$ & 0.57 \\
\hline In vitro dry matter degradability (\%) & $62.12^{\mathrm{a}}$ & $57.70^{\mathrm{b}}$ & $56.07^{\mathrm{b}}$ & $54.28^{\mathrm{b}}$ & 0.70 \\
\hline In vitro crude protein degradability (\%) & $64.67^{\mathrm{a}}$ & $60.61^{\mathrm{b}}$ & $59.89^{\mathrm{b}}$ & $58.80^{\mathrm{b}}$ & 0.71 \\
\hline In vitro organic matter degradability (\%) & $66.55^{\mathrm{a}}$ & $62.08^{\mathrm{b}}$ & $60.98^{\mathrm{b}}$ & $59.44^{\mathrm{b}}$ & 0.63 \\
\hline
\end{tabular}

\section{Conclusions}

The finding from this study can be concluded that cashew nut shell liquid inclusion at varying levels had a significant effect on in vitro gas, methane gas, ammonia-N and TVFA production. Although the addition of CNSL increased TVFA formation, it however decreased TVFA formation at higher inclusion levels. This result gives a good indication for improved utilization of dietary energy without the use of antibiotics thereby promising safer animal products for human consumption. It also supports the hypothesis that CNSL inclusion in ruminant diet can reduce methane and ammonia production thereby decreasing $\mathrm{GHG}\left(\mathrm{CH}_{4}\right.$ and $\left.\mathrm{N}_{2} \mathrm{O}\right)$ emissions into the atmosphere. Thus, this paper adds to the evidence that CNSL, which is an essential oil, serve as an eco-friendly feed additive for nutrient optimization and for combating GHG emissions in ruminant production.

\section{Acknowledgements}

The authors wish to express their appreciation to Tertiary Education Trust Fund, University Grant Management of Federal University of Agriculture Abeokuta (FUNAAB), Nigeria and Department of Animal Science, Tshwane University of Technology, Pretoria, South Africa for sponsoring the publication of this study.

\section{Conflict of Interest}

The author declare no conflict of interest.

\section{References}

Aminah A, Chen CP (1991) Future Prospects for Fodder and Pasture Production. In Feeding dairy cows in the tropics. Proceedings of the FAO expert consultation held in Bangkok, Thailand, 1989. Food and Agriculture Organization of the United Nations, Rome.

AOAC (1990) Official methods of analysis of the Association of Official Analytical Chemists. 2 (15). Washington, DC

AOAC (2000) Official Methods of Analysis. 17 $7^{\text {th }}$ ed. of the Association of Official Analytical Chemists. Gaithersburg, Maryland, USA.

Asaolu VO, Odeyinka SM, Binuomote RT, Odedire JÁ, Babayemi OJ (2014) Comparative nutrititive evaluation of Panicum maximum, selected tropical browses and their combinations using in vitro grass production technique. Agriculture and Biology Journal of North America.

Babayemi OJ, Bamikole MA (2006) Effect of Tephrosia candida leaf and its bag degradability of roughages in predicting feed intake in cattle. Animal Feed Science and Technology 40:109-119.

Busquet M, Calsamiglia S, Ferret A, Kamel C (2006) Plant extracts affect in vitro rumen microbial fermentation. Journal Dairy Science 89:761-771.

Calsamiglia S, Busquet M, Cardozo PW, Castillejos L, Ferret A (2007) Essential oils as modifiers of rumen microbial fermentation. Journal of Dairy Science 90:2580-95. 
Castillejos L, Calsamiglia S, Ferret A (2006) Effect of essential oil active compounds on rumen microbial fermentation and nutrient flow in in vitro systems. Journal of Dairy Science 89:2649-2658

Evans JD, Martin AS (2000) Effects of thymol on ruminal microorganisms. Current Microbiology 41:336-340.

Fievez V, Babayemi OJ, Dameyer D (2005) Estimation of direct and indirect gas production in syringes: a tool to estimate short chain fatty acid production requiring inimal laboratory facilities. Animal Feed Science and Technology 123:197-210.

Gallardo MR, Castilo AR, Bargo F, Abdala AA, Maciel MG, PerezMonti H, Castro HC, Castelli ME (2005) Monensin for lactating dairy cows grazing mixed alfafa pasture and supplemented with partial mixed ration. Journal Dairy Science 88:644-652.

Getachew G, Depeters EJ, Robinson PH, Taylor SJ (2001) In vitro rumen fermentation and gas production: Influence of yellow grease, tallow, corn oil and their potassium soaps. Animal Feed Science and Technology 93:1-15.

Gebrehiwot T (2014) Rumen manipulation for enhanced feed utilization and improved productivity performance of ruminants: A review. Momona Ethopian Journal of Science 6:3-17.

Geelen SN, Blazquez C, Geelen MJ, Van Oldruitenborgh-Oosterbaan MMS, Beynen AC (2001) High fat intake lowers hepatic fatty acid synthesis and raises fatty acid oxidation in aerobic muscle in Shetland ponies. British Journal of Nutrition 86:31-36.

Holmes CW, Brookes IM, Garrick DJ, Mackenzie DD, Parkinson TJ, Wilson GF (2006) Milk Production from Pasture: Principles and Practices. Nutrition: Classification and utilization of nutrients. Massey University, Palmerston North.

Hong D, Xiangzhou Z, Yushu Z, Jing Z, Deli C (2017) Gaseous losses of fertilizer nitrogen from a citrus orchard in the red soil hilly region of Southeast China. Soil Science and Plant Nutrition 63:419425

Jouany JP, Morgavi DP (2007) Use of 'natural' products as alternatives to antibiotic feed additives in ruminant production. The Animal Consortium 1:1443-1466.

Kozubek A, Zarnowski R, Stasiuk M, Gubernator J (2001) Natural amphiphilic phenols as bioactive compounds. Cellular and Molecular Biology Letters 6:351-355.

Manero A, Vilanova X, Cerda-Cuellar M, Blanch AR (2006) Vancomycin- and erythromycin-resistant enterococci in a pig farm and its environment. Environmental Microbiology 8:667-674.

McDougall S, Young L, Anniss FM (2004) Production and health of pasture-fed dairy cattle following oral treatment with the ionophore lasalocid. Journal of Dairy Science 87:2967-2976.

McIntosh FM, Williams P, Losa R, Wallace RJ, Beever DA, Newbold CJ (2003) Effects of essential oils on ruminal microorganisms and their protein metabolism. Applied and Environmental Microbiology 69:5011-5014.

Menke KH, Steingass H (1988) Estimation of the energetic feed value from chemical analysis and in vitro gas production using rumen fluid. Animal research and development 28:7-55.
National Research Council: NRC (1981) Nutritional energetic of domestic animals and glossary of terms.2nd Revision. Washington, DC, National Academy Press for National Research Council (NRC).

Nezhad MT, Alipour D, Goudarzi MT, Zamani P, Khoudakaramian G (2011) Dose Response to Carvone Rich Essential Oils of Spearmint (Mentha Spicata L) In vitro Ruminant Fermentation Kinetics and Digestibility. Journal Agricultural Science Technology 13:1013-1020.

Ogino A, Kaku K, Osada T, Shimada K (2004) Environmental impacts of the Japanese beef-fattening system with different feeding lengths as evaluated by a life-cycle assessment method. Journal of Animal Science 82:2115-2122.

Oonincx DGAB, van Itterbeeck J, Heetkamp MJW, Van den Brand H, van Loon JJA (2010) An Exploration on Greenhouse Gas and Ammonia Production by Insect Species Suitable for Animal or Human Consumption. PLoS ONE 5:e14445.

Parveen S, Lukasik J, Scott TM, Tamplin ML, Portier KM, Sheperd S, Braun K, Farrah SR (2006) Geographical variation in antibiotic resistance profiles of E.coli isolated from swine poultry beef and dairy cattle farm water retention ponds in Florida. Journal of Applied Microbiology. 100:50-57.

Pauzenga U (1985) Feeding parent stock. Journal of Zoological Technology International 22-24.

SAS (2010) Institute and SAS Publishing, SAS/IML Studio 3.3 for SAS/STAT Users. SAS institute

Santra A, Karim SA (2003) Rumen manipulation to improve animal productivity. Asian-Australian Journal of Animal Science 5:748-763

Sirohi SK, Mahta M, Goel N, Pandey P (2012) Effect of herbal plants oil addition in total mixed diets on anti-methanogenic activity, rumen fermentation and gas fermentation kinetics in vitro. Journal of Natural Product and Plant Resouces 2:3-80.

Shinkai T, Enishi O, Mitsumori M, Hiquchi K, Kobayashi Y, Takenaka A, Nagashima K, Mochizuki M, Kobayash YI (2012) "Mitigation of Methane Production from Cattle by Feeding Cashew Nut Shell Liquid. Journal of Dairy Science 95:9.

Van soest, PJ, Robertson JB, Lewis BA (1991) Methods for dietary fibre, neutral detergent and non-starch polysaccharides in relation to animal nutrition. Journal of Dairy Science 74:3583-3597

Wang CJ, Wang SP, Zhou H (2009) Influences of flavomycin, ropadiar and saponin on nutrient digestibility, rumen fermentation and methane emission from sheep. Animal Feed Science and Technology 148:157-166.

Wrage N, Velthof GL, van Beusichem ML, Oenema O (2001) Role of nitrifier denitrification in the production of nitrous oxide. Soil Biology \& Biochemistry 33:1723-1732.

Yang S, Carlson K (2004) Routine monitoring of antibiotics in water and wastewater with a radioimmunoassay technique. Water Research 38:3155-3166. 